\title{
Role of Tegmental Cholinergic Neurons in Dopaminergic Activation, Antimuscarinic Psychosis and Schizophrenia
}

John S. Yeomans, Ph.D.

Cholinergic neurons of the pedunculopontine nucleus (Ch5) and laterodorsal tegmental nucleus (Ch6) monosynaptically activate dopamine neurons of the substantia nigra, zona compacta ( $A 9$ ), and ventral tegmental area (A10) via muscarinic and nicotinic receptors. Ch5 cells and Ch6 cells are inhibited by local injections of muscarinic agonists, suggesting the presence of autoreceptors. This review advances the hypothesis that the psychotogenic effects of antimuscarinics are triggered by disinhibition of $\mathrm{Ch} 5$ and Ch6 cells via their autoreceptors, and that these effects are distinct from the memory-blocking effects of antimuscarinics mediated through the Ch1-Ch4 projections to the forebrain.

Neuroleptic and antiparkinson agents with antimuscarinic effects selectively block $m 1$ muscarinic receptors, whereas psychotogenic antimuscarinics are nonselective. In rats, scopolamine injected near Ch5 cells facilitates rewarding brain stimulation and induces locomotion and stereotypy, apparently via activation of dopaminergic systems. Systemically administered scopolamine induces locomotion and stereotypy via muscarinic receptors near Ch5 cells. Ch5 activation and Ch6 activation may be a causal factor in some forms of schizophrenia. Some schizophrenics show early-onset REM sleep, a condition that can result from $\mathrm{Ch} 5$ and Ch6 cholinergic activation of the pontine reticular formation. Schizophrenics with early-onset REM, or visual hallucinations, show more severe positive symptoms and negative symptoms. Ch5 cells and Ch6 cells have been found in twice-normal numbers in a few brains of schizophrenics. Several genetic and onset factors for schizophrenia that may be linked to Ch5 cells are considered, as well as treatment strategies based on inhibition of Ch5 cells and Ch6 cells, or blockade of their terminals. [Neuropsychopharmacology 12:3-16, 1995]
KEY WORDS: Cholinergic receptors; Psychoses, substance induced; Schizophrenia; Scopolamine; Dopamine; Reward

Although overactivation of dopamine systems is believed by many to be important for the expression of positive symptoms of schizophrenia (Mattysse 1973; Seeman et al. 1975; Creese et al. 1976; Seeman 1992), it is not clear how this overactivation occurs, how it lasts so long, or why the overactivation is not corrected by

From the Department of Psychology, University of Toronto, Toronto, Canada.

Address reprint requests to John S. Yeomans, Ph.D., Department of Psychology, University of Toronto, Toronto, Canada M5S 1A1.

Received March 29, 1993; revised June 23, 1994; accepted July 2, 1994. self-regulation of dopamine cells (Meltzer and Stahl 1976; Grace 1991). Although neuroleptics block positive symptoms primarily via $\mathrm{D} 2$ receptors, the dopamine hypothesis has difficulty explaining why other symptoms are not blocked by neuroleptics, why the beneficial effects of neuroleptics occur weeks after the onset of treatment, or why neuroleptics are ineffective in many patients. These problems have led many to propose that dopamine neurons may be one output system for more primary neural events (e.g., Freed 1989; Grace 1991), but no compelling candidate for a more primary neural cause has emerged. The goal of this paper is to propose such a candidate.

Recently, cholinergic neurons of the pedunculo- 
pontine nucleus (Ch5) and laterodorsal tegmental nucleus (Ch6) have been shown to monosynaptically contact tegmental dopamine neurons (Bolam et al. 1991), and strongly activate dopamine neurons via muscarinic and nicotinic receptors (Lacey et al. 1991; Calabresi et al. 1989). Cholinergic stimulation of $A 9$ and A10 dopamine cell groups, or of $\mathrm{Ch} 5$ and $\mathrm{Ch} 6$ cell groups in rats leads to reward facilitation, feeding, locomotion, and stereotypy, behaviors associated with dopaminergic activation with amphetamine (Yeomans et al. 1985, 1993; Winn 1991). This same cholinergic stimulation leads to a massive increase in dopamine efflux in striatum (Blaha and Winn 1993; Blackburn et al. 1994); therefore, activation of tegmental cholinergic neurons could be a direct source of dopaminergic activation.

Because antimuscarinics can induce a form of psychosis in humans and exacerbate schizophrenia, the hypothesis that cholinergic cells of the midbrain and pontine tegmentum are important in the psychotogenic effects of antimuscarinics and in schizophrenia is considered (Yeomans, 1992). Although mesopontine cholinergic alterations are proposed to be important, this is not a "single-transmitter," a "single-cause," or a "single-disease" hypothesis. Alterations of several types in serotonin, norepinephrine, dopamine, glutamate, or acetylcholine-containing cells, for example, could combine to alter the resulting activation in these systems in different schizophrenic populations.

Previous reviews of cholinergic mechanisms in schizophrenia have reached conflicting conclusions. Whereas some have emphasized that antimuscarinics administered systemically can induce positive and negative symptoms that resemble schizophrenia (Abood and Biel 1962; Baumgold et al. 1977; Lowy et al. 1977), others have emphasized the delirium, confusion, and memory loss that differentiate antimuscarinic psychosis and schizophrenia (Meltzer and Stahl 1976; Davis et al. 1978). Singh and Kay (1985) proposed that central cholinergic activity may be reduced in many schizophrenics. Tandon and Greden (1989) concluded that muscarinic hyperactivity leads to negative, not positive, symptoms of schizophrenia. Others have concluded that cholinergic mechanisms are not important to schizophrenia (Davis et al. 1978).

The difficulty in interpreting the effects of systemically administered muscarinics is that there are at least nine central cholinergic cell groups (in addition to motoneurons) and five types of muscarinic receptors:

1. Most interpretations discuss involvement of cholinergic interneurons of the striatum, or basal forebrain cholinergic cells (Ch1-4) that project to the forebrain. Four other projecting cholinergic cell groups (Ch5-8) have recently been described, along with many new anatomical connections (Mesulam et al. 1983; Rye et al. 1987; Woolf 1991).
2. Five types of muscarinic receptors $(\mathrm{m} 1-\mathrm{m} 5)$ have been genetically cloned (Kubo et al. 1986; Bonner et al. 1987; Peralta et al. 1987) and localized in the brain in relation to the cholinergic cell groups and their connections (Buckley et al. 1988; Weiner et al. 1990; Vilaro et al. 1990, 1991, 1992).

3. Neuroleptic and antiparkinson agents with an antimuscarinic action have been shown to selectively block the $m 1$ receptor, whereas the antimuscarinics that induce or worsen psychosis most potently are nonselective (Bolden et al. 1991).

4. Many cholinergic cells have autoreceptors, so that systemically administered drugs can have opposing effects on cholinergic cells or presynaptic terminals versus postsynaptic cells.

5. Local injections of muscarinic drugs in animals have identified sites that could mediate the central actions of systemically administered drugs.

Therefore, basic cholinergic mechanisms are reviewed here before addressing the thornier issues of how centrally acting muscarinics might work in human patients.

\section{ANATOMY AND PHYSIOLOGY OF Ch5 NEURONS AND Ch6 NEURONS}

Mesopontine cholinergic cells are located in a roughly continuous longitudinal band stretching from the caudal end of the substantia nigra to the floor of the fourth ventricle in rats, cats, and humans (Rye et al. 1987; Mesulam et al. 1989; Woolf 1991). The Ch5 cell group is located diffusely within and around the pedunculopontine tegmental nucleus (PPT). The Ch6 cell group is densely clustered in and around the laterodorsal tegmental nucleus (LDT) of the pons.

Ch5 and Ch6 cholinergic cells have widespread, overlapping projections. The heaviest projections are to the thalamus, to virtually all thalamic nuclei, but there are projections to the reticular formation, locus coeruleus, dorsal raphe, ventral tegmental area (VTA), substantia nigra, zona compacta, lateral hypothalamus, basal forebrain nuclei, and limbic frontal cortex, among others (Woolf 1991) (Figure 1).

$\mathrm{Ch} 5$ and $\mathrm{Ch} 6$ cells provide the only known cholinergic inputs to VTA and substantia nigra. Early doubts about these connections (e.g., Sugimoto and Hattori 1984; Rye et al. 1987) have been resolved by several recent studies (Clarke et al. 1987; Gould et al. 1989; Cornwall et al. 1990; Fujimoto et al. 1990; Woolf et al. 1990; Bolam et al. 1991). The lateral parts of substantia nigra receive projections mainly from more lateral $\mathrm{Ch} 5$ cells, whereas the medial substantia nigra and VTA appear to receive projections from medial $\mathrm{Ch} 5$ and from $\mathrm{Ch} 6$ cells (Jackson and Crossman 1983; Gould et al. 1989; Cornwall et al. 1990). 


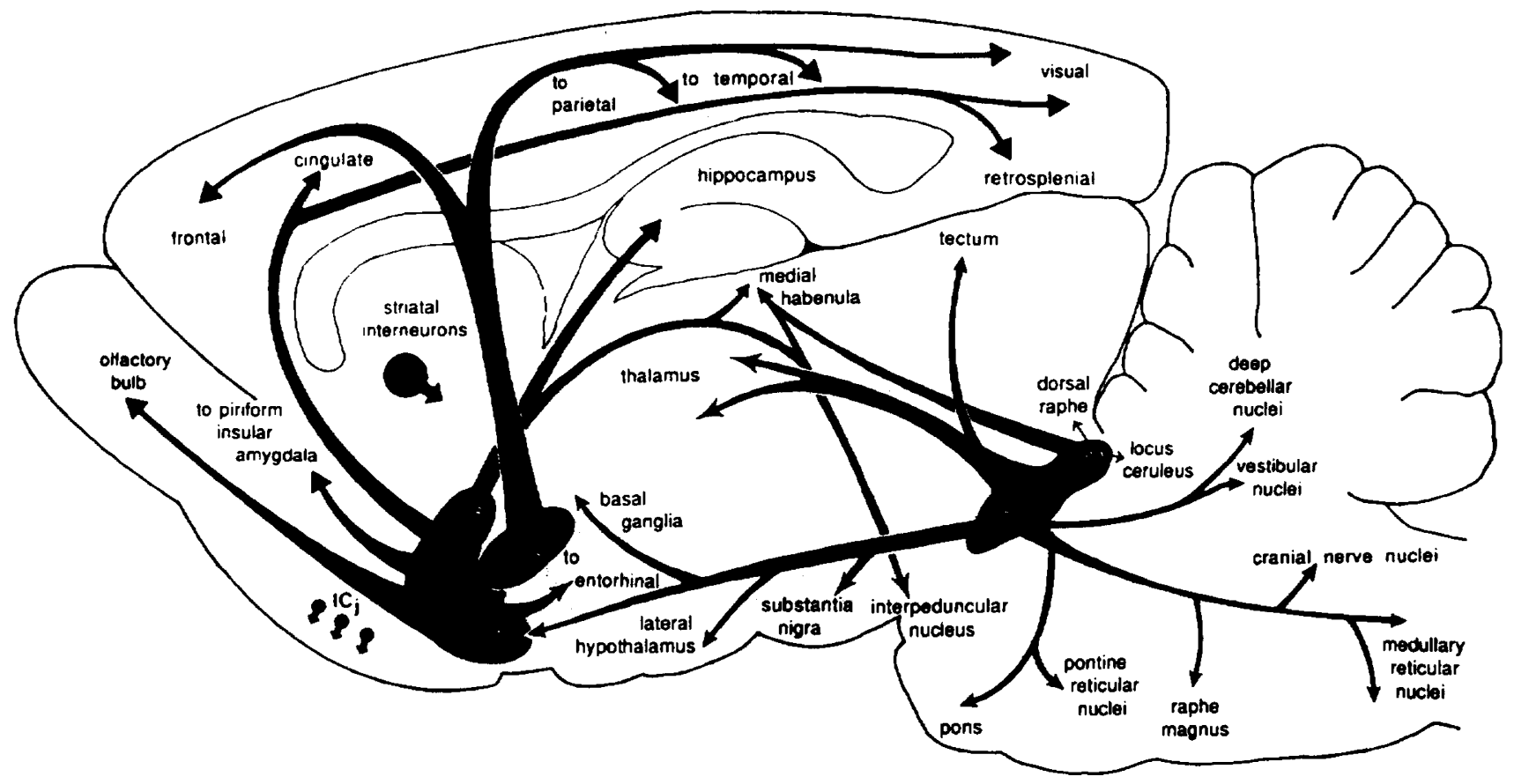

Figure 1. Schematic overview of cholinergic cell groups and projections. The entire cortical mantle is innervated by the basal forebrain subsystem (Ch1-Ch4) and the subcortical mass is innervated by the mesopontine subsystem (Ch5-Ch6). Minor cell groups in the habenula (Ch7) and parabigeminal nucleus (Ch8) are not shown (from Woolf 1991).

Near dopamine cells, low to moderate densities of nicotinic and muscarinic receptors are found in the rat brain and in the human brain (e.g., Cortes et al. 1984; Mash and Potter 1986). Selective lesions of these dopamine cells with 6-hydroxydopamine result in loss of both nicotinic and muscarinic receptors in rats (Clarke and Pert 1985; Vilaro et al. 1990), suggesting that both receptor classes are found only on the dopamine cells, or on terminals that require the presence of dopamine cells. High concentrations of acetylcholinesterase (AChE) are found in and around dopamine cells (Butcher and Woolf 1982; Greenfield 1991). ChAT-labelled terminals are found in substantia nigra, pars compacta, in low to moderate densities (Gould et al. 1989; Bolam et al. 1991), and these terminals make multiple asymmetric contacts onto the dendrites of dopamine cells (Bolam et al. 1991). The density of ChAT-labeled varicosities is higher in the VTA of humans than in the substantia nigra (Mesulam et al. 1992).

Cholinergic agonists nicotine, or muscarine directly activate VTA, or nigral dopamine cells recorded in rat midbrain slices (Calabresi et al. 1989; Lacey et al. 1991). The muscarinic actions were longer in duration, and more reliable on repeated tests than the nicotinic actions. There was no evidence of depolarization block or burst firing. In intact rats, carbachol or nicotine stimulation of the substantia nigra induced dopamine re- lease in the striatum, measured by voltammetry (Blaha and Winn 1993). Together these results indicate powerful and reliable activation of A9 dopamine cells and A10 dopamine cells by monosynaptic connections from $\mathrm{Ch} 5$ cholinergic cells and $\mathrm{Ch} 6$ cholinergic cells.

About $70 \%$ of synapses onto dopamine cells are symmetric GABAergic inhibitory synapses (Bolam et al. 1991). Of the chemically characterized asymmetric contacts, only acetylcholine and excitatory amino acids strongly excite dopamine neurons (Kalivas 1993). Cholinergic agonists induce a steady increase in firing, but glutamate induces oscillatory burst firing (Lacey et al. 1991; Johnson et al. 1992). 5HT-containing asymmetric contacts onto dopamine cells have mixed effects, but $5 \mathrm{HT}$ effects on cholinergic inputs appear to be inhibitory; $5 \mathrm{HT}$ causes $\mathrm{Ca}^{++}$to enter the dendrites of tegmental dopamine cells (Nedergaard et al. 1988), which leads to the release of dopamine and $\mathrm{AChE}$ from the dendrites (Llinas et al. 1984; Greenfield 1991). Therefore, $5 \mathrm{HT}$ can reduce cholinergic activation of dopamine cells by:

1. Dendritic release of dopamine, which then inhibits neighboring dopamine cells through autoreceptors.

2. Rapid enzymatic breakdown of acetylcholine released from cholinergic terminals.

3. Direct inhibition of $\mathrm{Ch} 5$ cholinergic cells and Ch6 
cholinergic cells, via raphe projections to these cholinergic cells (Luebke et al. 1992a; Semba and Fibiger 1992).

\section{Behaviors Induced by Cholinergic Stimulation of Dopamine and Ch5 Cells in Rats}

Cholinergic agonists injected near dopamine cells facilitate behaviors associated with dopamine stimulation. Carbachol $(1 \mu \mathrm{g}$ to $3 \mu \mathrm{g})$ injections into the VTA were rewarding to rats on a conditioned place preference task (Yeomans et al. 1985). Carbachol increased feeding when injected into the nigra (Parker et al. 1991; Winn 1991). Nicotine or cytisine increased locomotion when injected into the VTA (Reavill and Stolerman 1990).

Cholinergic blockers, atropine, scopolamine, or hemicholinium injected into VTA strongly inhibited brain-stimulation reward for electrodes placed in the hypothalamus, midbrain or pons (Yeomans et al. 1985; Kofman and Yeomans 1989; Kofman et al. 1990). The inhibitory effect of atropine was dose-dependent $(10 \mu \mathrm{g}$ to $60 \mu \mathrm{g})$, repeatable on subsequent days, and recovered gradually over a period of 2 hours. Preinjections of carbachol prevented the atropine blockade of brainstimulation reward, suggesting that the atropine effect is mediated via muscarinic receptors (Kofman et al. 1990). This atropine inhibition of reward was not accompanied by motor debilitation.

Injections of muscarinic agents near Ch5 cells in PPT produced the opposite effects. Carbachol blocked brainstimulation reward and reduced locomotor activity, whereas scopolamine $(100 \mu \mathrm{g})$ strongly facilitated brainstimulation reward and increased locomotor activity and stereotypical responses (Mathur and Yeomans 1993; Yeomans et al. 1993). These suggest that Ch5 cells are inhibited or disinhibited via "somatodendritic autoreceptors." Consistent with this idea, scopolamine injections into PPT increased dopamine efflux in the striatum (Blackburn et al. 1994).

The connections of Ch5 cells to dopamine cells may also be critical for drug rewards. Bilateral excitotoxic lesions of PPT blocked conditioned place preferences for opiate and stimulant drugs (Bechara and van der Kooy 1989, 1992; Bechara et al. 1992). Lesions of VTA dopamine cells with 6-OHDA blocked the self-administration of nicotine (Corrigall et al. 1992). Therefore, cholinergic activation of $\mathrm{A} 9$ and $\mathrm{A} 10$ dopamine cells by $\mathrm{Ch} 5$ and Ch6 inputs appears important for a variety of dopaminerelated functions including reward, feeding, hyperactivity, and stereotypy. In particular, scopolamine in PPT induces stereotypy, locomotion, and facilitation of brain-stimulation reward; phenomena that are similar to those produced by amphetamine injected systemically or in dopamine terminal areas.

Ch5 autoreceptors appear to be important in mediating the behavioral effects of systemically administered anticholinergics. Scopolamine ( $1 \mathrm{mg} / \mathrm{kg}$ to $10 \mathrm{mg} / \mathrm{kg}$ ) induces stereotypy and hyperactivity in rats (Arnfred and Randrup 1968; Shannon and Peters 1990), as well as dopamine release in the striatum (Blackburn et al. 1994). Carbachol preinjections in PPT reduced both the stereotypy and locomotion produced by systemic scopolamine (Yeomans et al. 1994). The carbacholinduced inhibition was not observed if the carbachol injections in PPT followed the systemic scopolamine injections suggesting competition for muscarinic receptors in PPT. Therefore, systemic scopolamine appears to act via mesopontine muscarinic autoreceptors rather than forebrain receptors.

\section{ANTIMUSCARINIC PSYCHOSIS}

Many antimuscarinic agents that cross the blood-brain barrier, including atropine, scopolamine, quinuclidinyl benzilate $(\mathrm{QNB})$, Ditran, and other piperidyl glycolates can at high doses evoke a psychotic state that includes tactile, visual, auditory and olfactory hallucinations, hyperactivity, severe disruption of thinking, including memory loss and confusion, as well as peripheral antimuscarinic effects and hyperthermia (Abood and Biel 1962; Grancher and Baldessarini 1975; Mego et al. 1988; Fischer 1991). The visual hallucinations can involve clearly defined objects such as people and animals and are often colorful. The auditory hallucinations can involve music or voices with subjects sometimes carrying on long conversations with these voices.

At low doses, subjects have difficulty sustaining attention, but can accurately describe their hallucinations and delusions which resemble those of endogenous schizophrenia (Abood and Biel 1962; Wilson and Shagass 1964; Singh and Kay 1985). The next day there is good recall of these experiences. At higher doses the subjects lose the ability to reason clearly and then to distinguish fantasy from reality, and eventually become incoherent (Meduna and Abood 1959; Fischer 1991).

Elderly people and those with a history of psychosis appear to be most susceptible to antimuscarinic psychosis (Mego et al. 1988; Ziskind 1988; Farley 1992). Several reports describe psychosis in elderly people who overused transdermal ear patches containing scopolamine as an antidote against nausea or motion sickness. Schizophrenics who take massive doses of antiparkinson drugs, especially trihexiphenidyl are also susceptible (Smith 1980; Fisch 1987).

By comparison, amphetamine psychosis also can produce florid auditory, olfactory, tactile and visual hallucinations, but there is less thought disorganization, difficulty in sustaining attention and delirium than with antimuscarinic psychosis (Snyder 1973). With amphetamine psychosis, the cardinal characteristic is paranoia. 
Confusion, memory loss, and peripheral side effects are diagnostic for "toxic cholinergic syndrome."

In some cases of antimuscarinic psychosis, delusions and hallucinations occur without delirium, confusion or memory loss (Meduna and Abood 1959; Fisher 1991); therefore, confusion and memory loss can be thought of as additional features of antimuscarinic psychosis that are not necessarily linked to the delusions and hallucinations.

\section{PROPOSED MECHANISMS OF ANTIMUSCARINIC PSYCHOSIS}

Antimuscarinic psychotogens are all nonspecific in their actions. For example, they block all five muscarinic receptor types, $\mathrm{m} 1$ to $\mathrm{m} 5$, effectively (Table 1 ). By contrast, neuroleptics with antimuscarinic effects and antiparkinson antimuscarinics induce or worsen psychosis only at much higher doses (Singh and Kay 1985; El-Yousef et al. 1973). Neuroleptics and antiparkinson drugs are all highly selective $\mathrm{m} 1$ (and sometimes $\mathrm{m} 4$ ) blockers (Table 1), which accounts for their therapeutic advantage. The psychotogenic effects of antimus- carinics, therefore, cannot occur primarily via $\mathrm{m} 1$ receptors or $\mathrm{m} 4$ receptors.

These $\mathrm{m} 1$ and $\mathrm{m} 4$ receptors are almost entirely localized to the forebrain (Figure 2). In the striatum, muscarinic receptors are primarily $\mathrm{m} 1$ receptors and $\mathrm{m} 4$ receptors, with $\mathrm{m} 2$ receptors found on the cholinergic interneurons as autoreceptors (Vilaro et al. 1991; Bernard et al. 1992). This suggests that antiparkinson antimuscarinics act primarily on the forebrain with the striatum a likely target. The muscarinic receptors on dopamine cells are exclusively of the $\mathrm{m} 5$ type (Vilaro et al. 1990); therefore, if antimuscarinics produced psychosis by blocking $\mathrm{m} 5$ receptors, the effect of muscarine on dopamine cells should be inhibitory. Because the effect of muscarine on dopamine cells is clearly excitatory (Lacey et al. 1991), m5 receptors are also unlikely to be the site of psychotogenic action; therefore, $\mathrm{m} 2$ receptors and $\mathrm{m} 3$ receptors are the remaining candidates.

About $70 \%$ of muscarinic receptors in brainstem, including PPT and LDT, are of the $\mathrm{m} 2$ type ( $\mathrm{Li}$ et al. 1991; Vilaro et al. 1992) with low quantities of other receptors (Vilaro et al. 1991; Wall et al. 1991a,b). The

Table 1. Binding (Kd) of Various Antimuscarinic Agents with Genetically

Cloned Human Muscarinic Receptors (m1-m5).

\begin{tabular}{|c|c|c|c|c|c|c|}
\hline & \multirow[b]{2}{*}{$\mathrm{m} 2 / \mathrm{ml}$} & \multicolumn{5}{|c|}{$\begin{array}{l}\text { Human Muscarinic Subtype } \\
\text { (Mean Kd } \pm \text { SEM in } n M \text { ) }\end{array}$} \\
\hline & & m1 & $\mathbf{m} 2$ & m3 & m4 & m5 \\
\hline \multicolumn{7}{|l|}{$\begin{array}{l}\text { Psychotogens with } \\
\text { anti-muscarinic } \\
\text { actions }\end{array}$} \\
\hline QNB & 0.77 & $0.035 \pm 0.002$ & $0.027 \pm 0.002$ & $0.088 \pm 0.003$ & $0.034 \pm 0.002$ & $0.043 \pm 0.003$ \\
\hline Atropine & 1.8 & $0.50 \pm 0.03$ & $0.90 \pm 0.03$ & $1.1 \pm 0.2$ & $0.6 \pm 0.1$ & $1.7 \pm 0.1$ \\
\hline Scopolamine & 1.8 & $1.1 \pm 0.2$ & $2.0 \pm 0.1$ & $0.44 \pm 0.01$ & $0.8 \pm 0.2$ & $2.07 \pm 0.01$ \\
\hline \multicolumn{7}{|c|}{$\begin{array}{l}\text { Antiparkinsonians with } \\
\text { antimuscarinic } \\
\text { actions }\end{array}$} \\
\hline Benztropine & 6.1 & $0.231 \pm 0.005$ & $1.4 \pm 0.1$ & $1.1 \pm 0.1$ & $1.1 \pm 0.1$ & $2.8 \pm 0.1$ \\
\hline Biperiden & 13.1 & $0.48 \pm 0.02$ & $6.3 \pm 0.5$ & $3.9 \pm 0.1$ & $2.4 \pm 0.3$ & $6.3 \pm 0.1$ \\
\hline Trihexyphenidyl & 4.4 & $1.6 \pm 0.2$ & $7 \pm 1$ & $6.4 \pm 0.4$ & $2.6 \pm 0.4$ & $15.9 \pm 0.1$ \\
\hline Procyclidine & 5.4 & $4.6 \pm 0.7$ & $25 \pm 2$ & $12.4 \pm 0.4$ & $7 \pm 1$ & $24 \pm 1$ \\
\hline \multicolumn{7}{|c|}{$\begin{array}{l}\text { Neuroleptics with anti- } \\
\text { muscarinic actions } \\
(A=\text { atypical })\end{array}$} \\
\hline Thioridazine & 5.2 & $2.7 \pm 0.3$ & $14 \pm 3$ & $15 \pm 1$ & $9 \pm 1$ & $13 \pm 1$ \\
\hline Clozapine (A) & 15.5 & $3.1 \pm 0.7$ & $48 \pm 1$ & $20 \pm 1$ & $11 \pm 1$ & $11.2 \pm 0.4$ \\
\hline Fluperlapine (A) & 8.1 & $8.8 \pm 0.2$ & $71 \pm 2$ & $41 \pm 6$ & $14 \pm 2$ & $17 \pm 1$ \\
\hline Mesoridazine & 1.5 & $10 \pm 1$ & $15 \pm 3$ & $90 \pm 2$ & $19 \pm 2$ & $60 \pm 10$ \\
\hline Chlorprothixene & 2.5 & $11 \pm 1$ & $28 \pm 3$ & $22 \pm 1$ & $18 \pm 2$ & $25 \pm 1$ \\
\hline Zotepine (A) & 7.8 & $18 \pm 6$ & $140 \pm 14$ & $73 \pm 4$ & $77 \pm 4$ & $260 \pm 20$ \\
\hline Chlorpromazine & 6.0 & $25 \pm 3$ & $150 \pm 14$ & $67 \pm 4$ & $40 \pm 3$ & $42 \pm 2$ \\
\hline Loxapine & 4.7 & $63.9 \pm 0.9$ & $300 \pm 100$ & $390 \pm 45$ & $300 \pm 20$ & $241 \pm 8$ \\
\hline \multicolumn{7}{|c|}{$\begin{array}{l}\text { Prototypic M1 selective } \\
\text { antimuscarinic }\end{array}$} \\
\hline Pirenzepine & 33.8 & $8 \pm 1$ & $270 \pm 10$ & $150 \pm 10$ & $28 \pm 1$ & $170 \pm 10$ \\
\hline
\end{tabular}

Psychotogenic antimuscarinics are all non-selective. Antiparkinsonian and neuroleptic agents with muscarinic binding are all $\mathrm{m} 1$ selective, with a secondary $\mathrm{m} 4$ selectivity. (Based on Bolden et al., 1991) 


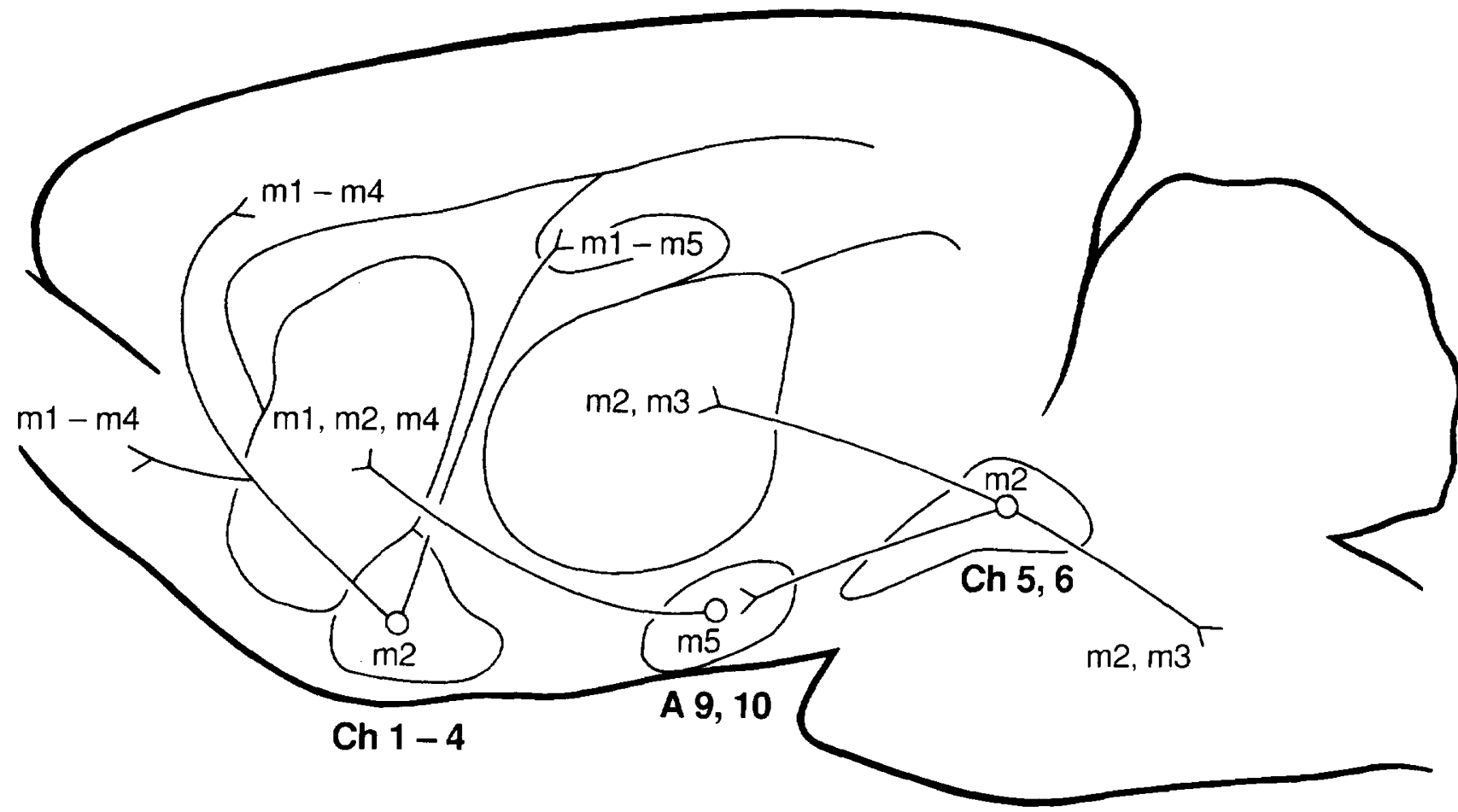

Figure 2. Distribution of genetically cloned muscarinic receptor types (m1-m5), schematically shown in relationship to major cholinergic (Ch1-Ch4, Ch5-Ch6) and dopaminergic (A9-A10) projections. Original figure based on data from Vilaro et al. 1990, 1991, 1992; Weiner et al. 1990; Li et al. 1991; Wall et al. 1991, 1992.

autoreceptors on Ch5 cells and Ch6 cells are likely to be of the $\mathrm{m} 2$ type (Leonard and Llinas 1988; Luebke et al. 1992b; Vilaro et al. 1992) as they are in striatum and cortex (Lapchak et al. 1989; Bernard et al. 1992).

The ability of systemic antimuscarinics to induce psychosis in humans is closely related to their ability to induce hyperactivity and behavioral disturbance in rats (Abood and Biel 1962; Baumgold et al. 1977). As discussed previously, hyperactivity and stereotypy induced by systemic scopolamine in rats is mediated mainly via muscarinic receptors near PPT (Yeomans et al. 1994). This suggests that the ability of antimuscarinics to induce psychosis is associated with their ability to block autoreceptors in PPT. It is proposed, therefore, that antimuscarinic psychosis (not including the memory loss) in humans results from the blockade of mesopontine autoreceptors.

Ch5 cells and Ch6 cells project heavily to the thalamus, diffusely activating these thalamic systems (Steriade et al. 1990). Muscarinic activation of thalamus in turn induces diffuse cortical activation and EEG desynchronization, and is believed to result in poor sensory filtering. Therefore, diffuse thalamic activation by $\mathrm{Ch} 5$ systems and Ch6 systems may worsen the confusion and inability to inhibit thoughts or external stimuli in antimuscarinic psychosis.

The memory inhibiting effects of antimuscarinics have been associated with blockade of Ch1-4 cholinergic projections to the cerebral cortex (Bartus et al. 1982; Coyle et al. 1983). Therefore, the delirium and memory loss observed during antimuscarinic psychosis may depend upon the sensitivity of cortical cholinergic systems (Ch1-4), whereas the delusions and hallucinations may be associated with brain stem cholinergic systems (Ch5, Ch6).

In conclusion, it is proposed that the psychotogenic actions of antimuscarinics occur via $\mathrm{m} 2$ autoreceptors on the Ch5 cholinergic cells and Ch6 cholinergic cells, whereas the antiparkinson effects and memory deficits occur via $\mathrm{m} 1$ receptors in the forebrain.

\section{Ch5 AND Ch6 CELLS AND SCHIZOPHRENIA}

Could activation of $\mathrm{Ch} 5$ cells and $\mathrm{Ch} 6$ cells be a route for the induction or exacerbation of schizophrenia? Links between these cells and some types of schizophrenia are found in studies of REM sleep, postmortem brains, drug abuse, and symptom severity in schizophrenics.

\section{REM SLEEP IN SCHIZOPHRENICS}

The similarity of dreams and schizophrenic hallucinations has interested many psychiatrists (e.g., Gillin and 
Wyatt 1975), but objective evidence for this link has been difficult to obtain. EEG studies show that most parameters of sleep are normal in schizophrenics. The most consistent difference (in inconsistent literature) is decreased mean REM latency in schizophrenics versus normals (Feinberg and Hiatt 1978; Keshevan et al. 1990; Tandon et al. 1992), but decreased delta wave amplitude and duration has also been observed in several studies (Caldwell 1969; Feinberg and Hiatt 1978). Although most schizophrenics are normal in REM latency, $10 \%$ to $30 \%$ of schizophrenics have sleep-onset REM (i.e., REM in first 15 minutes of sleep), a condition rarely observed in normals (Taylor et al. 1991). The exceptional schizophrenics, therefore, account for most of the small mean difference.

Schizophrenics with early-onset REM tend to have severe symptoms, both positive and negative (Tandon et al. 1992). When all schizophrenic subjects were included together, REM latency correlated with both negative symptom severity $(\mathrm{r}=-0.52)$ and with positive symptom severity $(r=-0.41)$. When the groups were analyzed, the correlations were higher for previously drug-treated schizophrenics, but were insignificant for untreated schizophrenics. It is possible that severe schizophrenics are more likely to have had previous drug treatment, although the alternative hypothesis that the neuroleptics caused the REM changes is not excluded.

Although REM latency is also reduced in depressives, the pattern of sleep changes in depressives is different than in schizophrenics (Gillin et al. 1979; Tandon et al. 1992). In schizophrenics, the REM latency was not related to the severity of additional depressive symptoms, therefore, the mean REM latency change was not simply the result of concurrent depressive symptoms (Keshevan et al. 1990; Tandon et al. 1992).

REM onset can be initiated by cholinergic activation of the pontine reticular formation by $\mathrm{Ch} 5$ cells and Ch6 cells. Cholinergic agonists microinjected into the dorsocaudal pontine reticular formation of cats induce pontine-geniculate-occipital waves and REM onset (Katayama et al. 1986; Callaway et al. 1987). Spontaneous REM is blocked by muscarinic blockers in the same sites (Baghdoyan et al. 1984; Shiromani and Fishbein 1986). The cholinergic input to this pontine reticular formation area comes from $\mathrm{Ch} 5$ cells and $\mathrm{Ch} 6$ cells (Mitani et al. 1988; Shiromani et al. 1988). Lesions of Ch5 cells and Ch6 cells block REM sleep in cats (Webster and Jones 1988). Studies of peripheral cholinergic manipulations in humans have been interpreted as support for this model (Sitaram et al. 1978). In schizophrenics, administration of the cholinergic agonist RS86 shortens REM latency and increases REM density (Riemann et al. 1991). Therefore, severe schizophrenia appears to be associated with early-onset REM sleep, a condition that can result from cholinergic activation of the pontine reticular formation from $\mathrm{Ch} 5$ cells and $\mathrm{Ch} 6$ cells.

\section{POST MORTEM STUDIES}

There is substantial evidence that $\mathrm{Ch} 5$ cells are lost in Parkinson's disease and progressive supernuclear palsy (PSP). NADPHd-containing, that is, cholinergic (Vincent et al. 1983) cells in lateral PPT were decreased by about $40 \%$ in Parkinson's patients versus age-matched controls (Hirsch et al. 1987; Jellinger 1988). The loss was about $65 \%$ for PSP (Hirsch et al. 1987; Zweig et al. 1987), a disease that shares many symptoms with Parkinson's disease.

There is some evidence that $\mathrm{Ch} 5$ cell and Ch6 cell counts are increased in schizophrenia. Karson et al. (1991) discovered that NADPHd-containing cells were about twice as common in the PPT nuclei and LDT nuclei of four brains of schizophrenics as in five control brains (two alcoholics, one depressed, and two normals). The small standard errors in the control group, and the large standard errors in the schizophrenic group, imply that two of the brains from schizophrenics had much more than twice as many Ch5 cells and Ch6 cells. No difference was found in these brains in the number of neurons in the nearby locus coeruleus where noradrenergic neurons also show NADPHd. Recently, the sample size has been increased to nine brains of schizophrenics, with a mean increase of $60 \%$ in Ch 5 cells and $\mathrm{Ch} 6$ cells versus normals (Garcia-Rill personal communication).

Because cell number is usually dew mined before birth, Ch 5 cells and Ch 6 cells may be overproduced prenatally in these schizophrenics. This hypothesis is difficult to test, however, because schizophrenia cannot be diagnosed prenatally. If so, the increased number of NADPHd-containing cells could be a predisposing, genetically determined factor in some schizophrenics. Whether or how increased numbers of cholinergic cells might predispose to schizophrenia is not known.

Cholinergic enzyme estimates have been inconsistent (Singh and Kay 1985). McGeer and McGeer (1977) found higher overall levels of ChAT and AChE in the brains of schizophrenics than in the brains of controls, but Domino et al. (1973) found no difference. Both increased and decreased levels of ChAT and AChE have been reported in limbic structures, such as the septum, hippocampus, amygdala, and nucleus accumbens (Domino et al. 1973; Wise et al. 1974; Bird et al. 1977; McGeer and McGeer 1977). Of interest to the Ch5 hypothesis, McGeer and McGeer (1977) found AChE levels significantly increased over normals in four thalamic nuclei, all of which receive their cholinergic input from 
the $\mathrm{Ch} 5$ cell groups and $\mathrm{Ch} 6$ cell groups; over the entire thalamus, brains from schizophrenics had $53 \%$ more AChE.

\section{ABUSE OF CHOLINERGIC DRUGS BY SCHIZOPHRENICS}

Some schizophrenics self-administer high doses of antimuscarinic agents, especially trihexyphenidyl (Smith 1980; Fisch 1987). Schizophrenics smoke cigarettes at an unusually high rate ( $90 \%$ of schizophrenics, $33 \%$ of normals, $45 \%$ to $70 \%$ of other psychotics) which may indicate an increased tendency to self-administer nicotine (Hughes et al. 1986; Lohr and Flynn 1992). From the animal studies reviewed previously, one could speculate that the rewarding effects of nicotine occur through nicotinic receptors on dopamine cells, whereas the rewarding effects of antimuscarinics occur through muscarinic autoreceptors.

\section{ANTIMUSCARINICS AND SCHIZOPHRENIA}

When nonselective antimuscarinics are given to chronic schizophrenics, both positive and negative symptoms are exacerbated (Gershon and Olariu 1960; Tourlentes et al. 1960; El-Yousef et al. 1973; Singh and Smith 1973; Singh and Kay 1975). These symptoms were reported to resemble "true" schizophrenia better than acute antimuscarinic psychosis in normals (Gershon and Olariu 1960; Singh and Kay 1985), sometimes producing symptoms that were previously described at the onset of the illness (Gershon and Olariu 1960; El-Yousef et al. 1973). The psychosis could be induced or worsened in schizophrenics repeatedly with repeated administrations (Gershon and Olariu 1960), again suggesting the potential for chronic maintenance of the disease via cholinergic activation. The effects of lower clinical doses of antiparkinson antimuscarinics on schizophrenia appear to be weaker, however, especially on negative symptoms (Singh et al. 1987; Tandon et al. 1991).

Antimuscarinic psychosis at high doses usually involves a predominance of visual hallucinations, whereas schizophrenia usually involves a predominance of auditory hallucinations. Reevaluations of hallucinations in schizophrenia suggest that there is a higher prevalence of visual hallucinations than had previously been suspected (Goodwin et al. 1971; Bracha et al. 1989; Mueser et al. 1990). Although auditory hallucinations were associated with earlier onset of schizophrenia, visual hallucinations were the only hallucinations associated with global severity (Mueser et al. 1990). The high percentage of visual hallucinations $(56 \%$ of subjects) reported by Bracha et al. (1989) was attributed to the severity of schizophrenia in the patients at the NIMH research wards.
Schizophrenics with intense mesopontine cholinergic involvement may be a subpopulation, i.e. those showing severe global symptoms, disorganized thinking, visual hallucinations, and/or early-onset REM sleep. When activation of mesopontine cholinergic neurons is more gradual, weaker, or earlier in onset than with antimuscarinic psychosis, weaker positive symptoms and negative symptoms may result, involving more auditory hallucinations. Alternatively, mesopontine cholinergic activation may be only one contributing factor in the constellation of factors that lead to schizophrenia.

Differential responses to cholinergic drugs may also be useful in categorizing schizophrenics with cholinergic involvement. As mentioned previously, they are more inclined to self-administer nicotine (through cigarette smoking) or antimuscarinics. Singh and Kay (1985) concluded that paranoid schizophrenics are less responsive to cholinergic drugs than nonparanoid schizophrenics.

\section{CHOLINERGIC CASCADE}

Figure 3 shows a highly speculative proposal for how alterations in mesolimbic cholinergic neurons might lead to schizophrenia. Predisposing genetic factors could lead to (1) increased Ch5 cells and Ch6 cells, (2) too few or nonfunctional $\mathrm{m} 2$ autoreceptors on $\mathrm{Ch} 5$ cells and Ch6 cells, or (3) oversensitive long-term potentiation mechanisms on Ch5 cells and Ch6 cells.

The susceptibility to schizophrenia is very low in late childhood and increases through early adult years. Feinberg (1982) showed that delta-wave amplitude and duration follow the same developmental time course

\section{PROPOSED CHOLINERGIC CASCADE IN SCHIZOPHRENIA}

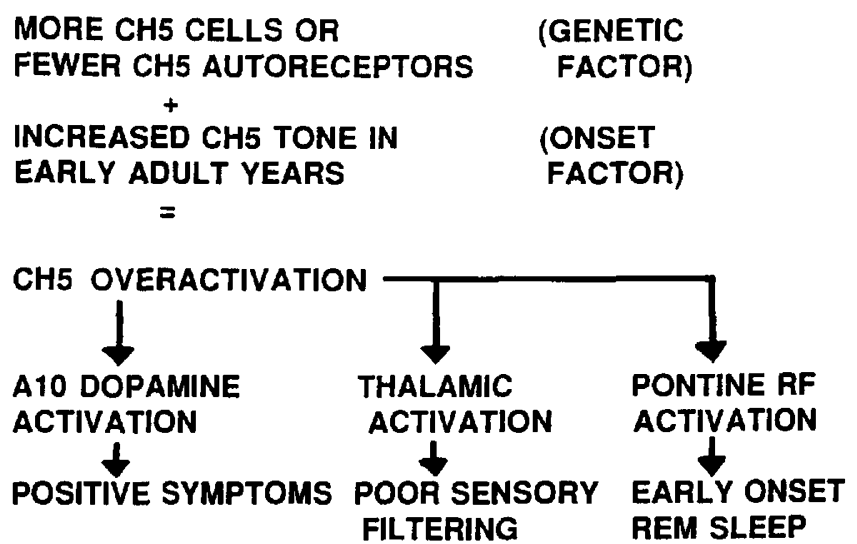

Figure 3. Cascade of events hypothesized to be important in cholinergic-linked schizophrenia. 
in normals, being low at birth, increasing in late childhood, then decreasing from ages 12 to 30 . Because deltawave duration and amplitude are greatest in the furst sleep cycle immediately before the first REM onset, this may indicate decreased cholinergic tone in late childhood and increased cholinergic tone in early adulthood in normals. Schizophrenics show either decreased delta-wave amplitude and duration or earlier-onset REM as compared to normal adults in most studies (Caldwell 1969; Feinberg and Hiatt 1978; Tandon et al. 1992); therefore, normal developmental changes in the sensitivity of Ch5 cells and Ch6 cells may make the mesopontine cholinergic systems of predisposed individuals more vulnerable to activation.

Reward systems provide an excitatory input to $\mathrm{Ch} 5$ cells. Exposure to rewarding drugs could alter the sensitivity of these cells and increase the likelihood of psychotic episodes being triggered.

Once Ch5 cells and Ch6 cells are chronically activated, overactivation of A10 dopamine cells could lead to increased positive symptoms. At high levels, Ch5 activation and $\mathrm{Ch} 6$ activation of the pontine reticular formation could lead to early-onset REM accompanied by visual hallucinations. Diffuse activation of the thalamus by $\mathrm{Ch} 5$ cells and $\mathrm{Ch} 6$ cells could result in an inability to filter information to be relayed to the cortex (Steriade et al. 1990), and disorganized thoughts.

\section{HYPOTHESES REGARDING THERAPY}

The slow onset of neuroleptic efficacy against positive symptoms is a problem for the dopamine hypothesis, because neuroleptics block dopamine-related behaviors and dopamine turnover quickly in animals. In animals pretreated with scopolamine, neuroleptics show reduced ability to block these dopamine-related behaviors, such as hyperactivity, brain-stimulation reward, stereotypy, catalepsy, and rotation (Morpurgo and Theobald 1964; Muller and Seeman 1974; Kelly and Miller 1975; Setler et al. 1976; Stephens and Herberg 1979; Murzi and Herberg 1982). Similarly, treatment with high doses of the antiparkinson antimuscarinic, benztropine, reduced the efficacy of neuroleptics in schizophrenia (Singh and Kay 1975). The strong effects of scopolamine on dopamine release and dopaminerelated functions suggest that the peculiar ineffectiveness of neuroleptics following scopolamine pretreatment may result from the action of scopolamine on mesopontine cholinergic cells, thereby reducing the immediate therapeutic advantage of neuroleptics. According to this argument, the slow onset of neuroleptic efficacy may indicate mesopontine cholinergic activation in schizophrenics.

If cholinergic activation is a primary causal factor in some types of schizophrenia, how could cholinergic- linked schizophrenia be treated? The usual treatment for antimuscarinic psychosis is to provide supportive care and to wait out the episode. Anticholinesterase treatment with Tacrine or physostigmine often reduces the severity of symptoms (Abood and Biel 1962; Heiser and Gillin 1971; El-Yousef et al. 1973; Grancher and Baldessarini 1975; Ziskind 1988). In terms of the Ch5, Ch6 hypothesis, anticholinesterase treatment may flood the unblocked autoreceptors with acetylcholine from dendrodendritic contacts, inhibiting the $\mathrm{Ch} 5$ cells and $\mathrm{Ch} 6$ cells.

Selective $\mathrm{m} 2$ muscarinic receptor agonists should inhibit $\mathrm{Ch} 5$ cells and $\mathrm{Ch} 6$ cells. In schizophrenics, transient improvements in symptoms have been reported with a variety of cholinergic agonists, including arecholine, pilocarpine (Pfeiffer and Jenney 1957), or the anticholinesterase, physostigmine (reviewed by Singh and Kay 1985). Several other studies found no effect or mixed effects, and the therapeutic effects often showed tolerance, therefore, these limited successes should be interpreted with caution. The peripheral and central side effects of $\mathrm{m} 2$ agonists and anticholinesterases are strong, limiting the doses that can be used to treat the psychosis.

Nonm 2 blockers might block the outputs of mesopontine cholinergic cells. In the 1950s and 1960s, comainducing doses of scopolamine ( $5 \mathrm{mg}$ to $100 \mathrm{mg}$ ) and atropine ( $32 \mathrm{mg}$ to $212 \mathrm{mg}$ ) were administered 3 times to 6 times a week to inhibit symptoms of psychosis (reviewed by Singh and Kay 1985). Improvements were found in $58 \%$ to $77 \%$ of schizophrenics in various categories in a study of several hundred patients (Goldner 1967). According to the Ch5, Ch6 hypothesis, these high, repeated doses might completely block postsynaptic muscarinic receptors, and prevent all cholinergic activation, resulting in a temporary relief of symptoms.

Selective $\mathrm{m} 5$ blockers should block the outputs of Ch 5 cells and Ch 6 cells to dopamine cells, and thereby block positive symptoms with fewer peripheral and central side effects (Yeomans 1992; Brann et al. 1993). In rats, cholinergic blockers in VTA, or medial substantia nigra induce little motor inhibition or turning (Kofman et al. 1991; Winn 1991). The weaknesses of this approach are:

1. The outputs of Ch5 cells and Ch 6 cells to basal forebrain, thalamus, and brain stem would not be blocked.

2. The effects on $\mathrm{m} 5$ receptors in other brain regions, such as hippocampus are not known.

3. No selective $\mathrm{m} 5$ blockers are available.

Noncholinergic inhibitors of $\mathrm{Ch} 5$ cells and $\mathrm{Ch} 6$ cells are serotonin (Luebke et al. 1992a), norepinephrine (Williams and Reiner 1992), and mu opiates (Serafin et 
al. 1990). The specific receptor types should be identified so that selective agents can be used for peripheral administration.

A combined strategy is needed. First, behaviors activated by muscarinic disinhibition of $\mathrm{Ch} 5$ cells and $\mathrm{Ch} 6$ cells should be challenged by appropriate systemic agents. Second, brain and receptor changes or behaviors that identify cholinergic involvement in psychosis should be further examined to identify which populations might benefit from cholinergic-based treatments. Third, linkage between $\mathrm{m} 2(7 \mathrm{q} 35-36)$ and $\mathrm{m} 5$ (15q 26) receptor genes and schizophrenia should be sought (Bonner et al. 1991).

\section{ACKNOWLEDGMENTS}

I thank A. Mathur, P. Shiromani, R. Greene, and A. Shandarin for commenting on an early draft of the manuscript.

\section{REFERENCES}

Abood LG, Biel JH (1962): Anticholinergic psychotomimetic agents. Int Rev Neurobiol 4:217-273

Arnfred T, Randrup A (1968): Cholinergic mechanism in brain inhibiting amphetamine-induced stereotyped behavior. Acta Pharmacol Toxicol 26:384-394

Baghdoyan HA, Rodrigo-Angula ML, McCarley RW, Hobson JA (1984): Site-specific enhancement and suppression of desynchronized sleep signs following cholinergic stimulation of three brainstem sites. Brain Res 306:39-52

Bartus RT, Dean RL, Beer B, Lippa AS (1982): The cholinergic hypothesis of geriatric memory dysfunction. Science 217:408-417

Baumgold J, Abood LG, Aronstam R (1977): Studies on the relationship of binding affinity to psychoactive and anticholinergic potency of a group of psychotomimetic glycolates. Brain Res 124:331-340

Bechara A, van der Kooy D (1989): The tegmental pedunculopontine nucleus: A brain-stem output of the limbic system critical for the conditioned place preferences produced by morphine and amphetamine. J Neurosci 9:3400-3409

Bechara A, van der Kooy D (1992): A single brain stem substrate mediates the motivational effects of both opiates and food in nondeprived rats, but not in deprived rats. Behav Neurosci 106:351-363

Bechara A, Harrington F, Nader K, van der Kooy D (1992): Neurobiology of motivation: Double dissociation of two motivational mechanisms mediating opiate reward in drug-naive versus drug-dependent animals. Behav Neurosci 106:798-807

Bernard V, Normand E, Bloch B (1992): Phenotypical characterization of the rat striatal neurons expressing muscarinic receptor genes. J Neurosci 12:3591-3600

Bird ED, Barnes J, Iversen LL, Spokes EG, Mackay AV, Shepherd M (1977): Increased brain dopamine and reduced glutamic acid decarboxylase and choline acetyl transferase activity in schizophrenia and related psychoses. Lancet ii:1157-1159

Blackburn JR, Chapman CA, Blaha CD, Yeomans JS (in preparation): Striatal dopamine levels increase following peripheral scopolamine injections and following application of scopolamine to the tegmental pedunculopontine nucleus. Soc Neurosci Abstr, submitted

Blaha CD, Winn P (1993): Modulation of dopamine efflux in the striatum following cholinergic stimulation of the substantia nigra in intact and pedunculopontine tegmental nucleus-lesioned rats. J Neurosci 13:1035-1044

Bolam JP, Francis CM, Henderson Z (1991): Cholinergic input to dopaminergic neurons in the substantia nigra: A double immunocytochemical study. Neurosci 41:483-494

Bolden C, Cusack B, Richelson E (1991): Antagonism by antimuscarinic and neuroleptic compounds at five cloned human muscarinic cholinergic receptors expressed in Chinese hamster ovary cells. J Pharm Exp Ther 260:576-580

Bonner TI, Modi WS, Seuanez HN, O’Brien SJ (1991): Chromosomal mapping of five human genes encoding muscarinic acetylcholine receptors. Cytog C Gen 58:1850-1851

Bonner TI, Buckley NJ, Young A, Brann MR (1987): Identification of a family of muscarinic acetylcholine receptor genes. Science 237:527-532

Bracha HS, Wolkowitz OM, Lohr JB, Karson CN, Bigelow LB (1989): High prevalence of visual hallucinations in research subjects with chronic schizophrenia. Am J Psychiatry 146:526 -528

Brann MR, Ellis J, Jorgenson H, Hill-Eubanks D, Jones SVP (1993): Muscarinic acetylcholine receptor subtypes: localization and structure/function. Prog Brain Res 98: 121-127

Buckley NJ, Bonner TI, Brann MR (1988): Localization of a family of muscarinic receptor mRNAs in rat brain. J Neurosci 8:4646-4652

Butcher LL, Woolf NJ (1982): Monoaminergic-cholinergic relationships and the chemical communication matrix of the substantia nigra and neostriatum. Brain Res Bull 9:475-492

Calabresi P, Lacey MG, North RA (1989): Nicotinic excitation of rat ventral tegmental neurones in vitro studied by intracellular recording. Br J Pharmacol 98:135-140

Callaway CW, Lydic R, Baghdoyan HA, Hobson JA (1987): Pontogeniculooccipital waves: Spontaneous visual system activity during rapid eye movement sleep. Cell Mol Neurobiol 2:105-149

Caldwell DF (1969): Differential levels of stage 4 sleep in a group of clinically similar chronic schizophrenic patients. Biol Psychiat 1:131-141

Clarke PBS, Hommer DW, Pert A, Skirboll LR (1987): Innervation of substantia nigra neurons by cholinergic afferents from pedunculopontine nucleus in the rat: neuroanatomical and electrophysiological evidence. Neuroscience 23:1011-1019

Clarke PBS, Pert A (1985): Autoradiographic evidence for nicotine receptors on nigrostriatal and mesolimbic neurons. Brain Res 348:355-358

Cornwall J, Cooper SD, Phillipson OT (1990): Afferent and 
efferent connection of the laterodorsal tegmental nucleus in the rat. Brain Res Bull 25:271-284

Corrigall WA, Franklin KBJ, Coen KM, Clarke PBS (1992): The mesolimbic dopaminergic system is implicated in the reinforcing effects of nicotine. Psychopharmacology 107:285-289

Cortes R, Probst A, Palacios JM (1984): Quantitative light microscopic autoradiographic localization of cholinergic muscarinic receptors in the human brain: Brainstem. Neuroscience 12:1003-1026

Coyle JT, Price DL, DeLong MR (1983): Alzheimer's disease: A disorder of cortical cholinergic innervation. Science 219:1184-1190

Creese I, Burt DR, Snyder SH (1976): Dopamine receptor binding predicts clinical and pharmacological potencies of antischizophrenic drugs. Science 192:481-483

Davis KL, Berger PA, Hollister LE, Barchas JD (1978): Cholinergic involvement in mental disorders. Life Sci 22: 1865-1872

Domino EF, Krause RR, Bowers J (1973): Various enzymes involved with putative neurotransmitters. Arch Gen Psychiatry 29:195-201

El-Yousef MK, Janowsky DS, Davis JM, Sekerke HJ (1973): Reversal of antiparkinonian drug toxicity by physostigmine: A controlled study. Am J Psychiatry 130:141-145

Farley T (1992): Check behind the ears. J Fam Prac 34:676-677

Feinberg I (1982): Schizophrenia: Caused by a fault in programmed synaptic elimination during adolescence? J Psychiatr Res 17:319-334

Feinberg I, Hiatt JF (1978): Sleep pattern in schizophrenia: A selective review. In: Williams RL, Karacan I, Frazier $\mathrm{SH}$ (eds), Sleep Disorders: Diagnosis and Treatment. New York, Wiley, pp 205-231

Fisch RZ (1987): Trihexyphenidyl abuse: Therapeutic implications for negative symptoms of schizophrenia? Acta Psychiatr Scand 75:91-94

Fischer CM (1991): Visual hallucinations on eye closure associated with atropine toxicity. A neurological analysis and comparison with other visual hallucinations. Can J Neurol Sci 18:18-27

Freed WJ (1989): An hypothesis concerning the antipsychotic effect of neuroleptic drugs. Pharm Biol B 32:337-345

Fujimoto K, Ikeguchi K, Yoshida M (1990): Decrease and recovery of choline acetyltransferase activity in medial thalamus and ventral tegmental area after destruction of pedunculopontine areas in the rat. Neurosci Res 9:48-53

Gershon S, Olariu J (1960): A new psychotomimetic: its antagonism by tetrahydroaminoacridine and its comparison with LSD, mescaline, and sernyl. J Neuropsychiatr 1:282-293

Gillin JC, Wyatt RJ (1975): Schizophrenia: Perchance a dream? Int Rev Neurobiol 17:297-342

Gillin JC, Duncan W, Pettigrew KD, Frankel BL, Snyder F (1979): Successful separation of depressed, normal and insomniac subjects by EEG sleep data. Arch Gen Psychiat 36:85-90

Goldner RD (1967): Scopolamine sleep treatment in private practice. Int J Neuropsychiat 3:234-247

Goodwin DW, Alderson P, Rosenthal R (1971): Clinical significance of hallucinations in psychiatric disorders. Arch Gen Psychiatry 24:76-80

Gould E, Woolf NJ, Butcher LL (1989): Cholinergic projections to the substantia nigra from the pedunculopontine and laterodorsal tegmental nuclei. Neuroscience 28: 611-623

Grace AA (1991): Phasic versus tonic dopamine release and the modulation of dopamine system responsivity: a hypothesis for the etiology of schizophrenia. Neuroscience 41:1-24

Granacher RP, Baldessarini RJ (1975): Physostigmine: Its use in acute anticholinergic syndrome with antidepressant and antiparkinson drugs. Arch Gen Psychiatry 32: 375-380

Greenfield SA (1991): A noncholinergic action of acetylcholinesterase (AChE) in the brain: From neuronal secretion to the generation of movement. Cell Mol Neurobiol 11:55-77

Heiser JF, Gillin JC (1971): The reversal of anticholinergic druginduced delirium and coma with physostigmine. Am J Psychiat 127:1050-1054

Hirsch EC, Graybiel AM, Duyckaerts C, Javoy-Agid F (1987) Neuronal loss in the pedunculopontine tegmental nucleus in Parkinson disease and in progressive supranuclear palsy. Proc Natl Acad Sci USA 84:5976-5980

Hughes JR, Hatsukami DK, Mitchell JE, Dahlgren LA (1986): Prevalence of smoking among psychiatric outpatients. Am J Psychiatry 143:993-997

Jackson A, Crossman AR (1983): Nucleus tegmenti pedunculopontinus: Efferent connections with special reference to the basal ganglia, studied in the rat by anterograde and retrograde transport of horseradish peroxidase. Neuroscience 10:725-765

Jellinger K (1988): The pedunculopontine nucleus in Parkinson's disease, progressive supranuclear palsy and $\mathrm{Alz}$ heimer's disease. JNeurol Neurosurg Psychiatr: 540-543

Johnson SW, Seutin V, North RA (1992): Burst furing in dopamine neurons induced by N-methyl-D-aspartate: role of electrogenic pump. Science 258:665-667

Kalivas PW (1993): Neurotransmitter regulation of dopamine neurons in the ventral tegmental area. Brain Res Rev 18:75-113

Karson CN, Garcia-Rill E, Biedermann J, Mrak RE, Husain MM, Skinner RD (1991): The brain stem reticular formation in schizophrenia. Psychiatr Res: Neuroimaging 40:31-48

Katayama Y, DeWitt DS, Becker DP, Hayes RL (1986): Behavioral evidence for cholinoceptive pontine inhibitory area: Descending control of spinal motor output and sensory input. Brain Res 296:241-262

Kelly PH, Miller RJ (1975): The interaction of neuroleptic and muscarinic agents with central dopaminergic systems. Brit J Pharmacol 54:115

Keshevan MS, Reynolds CF, Kupfer DJ (1990): Electroencephalographic sleep in schizophrenia: a critical review. Compr Psychiatry 30:34-47

Kofman O, McGlynn SM, Olmstead MC, Yeomans JS (1991): Differential effects of atropine, procaine, and dopamine in the rat ventral tegmentum on lateral hypothalamic rewarding brain stimulation. Behav Brain Res 38:55-68. 
Kofman O, Yeomans JS (1989): Cholinergic antagonists in ventral tegmentum elevate thresholds for lateral hypothalamic and brainstem self-stimulation. Pharmacol Biochem Behav 31:547-559

Kubo T, Fukuda K, Mikami A, Maeda A, Takahashi H, Mishina M, Haga K, Ichiyama A, Kangawa K, Kojima M, Matsuo H, Hirose T, Numa S (1986): Cloning, sequencing, and expression of complementary DNA encoding the muscarinic acetylcholine receptor. Nature 323:411-416

Lacey MG, Calabresi P, North RA (1991): Muscarine depolarizes substantia nigra zona compacta and ventral tegmental neurons in vitro through M1-like receptors. J Pharmacol Exp Ther 253:395-400

Lapchak PA, Araujo DM, Quirion R, Collier B (1989): Binding sites for [3H]AF-DX 116 and effect of AF-DX 116 on endogenous acetylcholine release from rat brain slices. Brain Res 496:285-294

Leonard CS, Llinas R (1988): Electrophysiology of thalamicprojecting cholinergic brainstem neurons and their inhibition by Ach. Soc Neurosci Abstr 14:297

Li M, Yasuda RP, Wall SJ, Wellstein A, Wolfe BB (1991): Distribution of $m 2$ receptors in rat brain using antisera selective for $\mathrm{m} 2$ receptors. Mol Pharmacol 40:28-35

Llinas R, Greenfield SA, Jahnsen H (1984): Electrophysiology of pars compacta cells in the in vitro substantia nigra-A possible mechanism for dendritic release. Brain Res 294: 127-132

Lohr JB, Flynn K (1992): Smoking and schizophrenia. Schiz Res 8:93-102

Lowy K, Abood ME, Drexler M, Abood LG (1977): Antagonism by cholinergic drugs of behavioural effects in cats of an anticholinergic psychotomimetic drug and enhancement by nicotine. Neuropharmacology 16:399-403

Luebke JI, Greene RW, Semba K, Kamondi A, McCarley RW, Reiner PW (1992a): Serotonin hyperpolarizes cholinergic low-threshold burst neurons in the rat laterodorsal tegmental nucleus in vitro. Proc Natl Acad Sci 89:743-747

Luebke JI, McCarley RW, Greene RW (1992b): Carbachol induced hyperpolarization of neurons in the rat laterodorsal tegmental nucleus in vitro. Soc Neurosci Abstr 18:975

Mash DC, Potter LT (1986): Autoradiographic localization of $\mathrm{M} 1$ and M2 muscarine receptors in the rat brain. Neuroscience 19:551-564

Mathur A, Yeomans JS (1993): Locomotion and stereotypy induced by microinjections of scopolamine into the pedunculopontine tegmental nucleus: Involvement of dopamine cells. Soc Neurosci Abstr 19:758

Matthews RT, German DC (1984): Electrophysiological evidence for excitation of rat ventral tegmental area dopamine neurons by morphine. Neuroscience 12:617-625

Mattysse S (1973): Antipsychotic drug actions: A clue to the neuropathology of schizophrenia? Fed Proc 32:200-205

McGeer PL, McGeer EG (1977): Possible changes in striatal and limbic cholinergic systems in schizophrenia. Arch Gen Psychiatry 34:1319-1323

Meduna LJ, Abood LG (1959): Studies of a new drug (Ditran) in depressive states. J Neuropsychiatr 1:1-3

Mego DM, Omori DJM, Hanley JF (1988): Transdermal scopolamine as a cause of transient psychosis in two elderly patients. Southern Med J 81:394-395
Meltzer HY, Stahl SM (1976): The dopamine hypothesis of schizophrenia: A review: Schizophrenia Bull 2:19-76

Mesulam MM, Mufson EJ, Wainer BH, Levey AI (1983): Central cholinergic pathways in the rat: An overview based on an alternative nomenclature. Neuroscience 10: 1185-1201

Mesulam MM, Geula C, Bothwell MA, Hersh LB (1989): Human reticular formation: cholinergic neurons of the pedunculopontine and laterodorsal tegmental nuclei and some cytochemical comparisons to forebrain cholinergic neurons. J Comp Neurol 281:611-633

Mesulam MM, Mash D, Hersh L, Bothwell M, Geula C (1992): Cholinergic innervation of the human striatum, globus pallidus, subthalamic nucleus, substantia nigra, and red nucleus. J Comp Neurol 323:252-268

Mitani A, Ito K, Hallanger AE, Wainer BH, Kataoka K, McCarley RW (1988): Cholinergic projections from the laterodorsal and pedunculopontine tegmental nuclei to the pontine gigantocellular tegmental field in the cat. Brain Res 451:397-402

Morpurgo C, Theobald W (1964): Influence of antiparkinson drugs and amphetamine on some pharmacological effects of phenothiazine derivatives used as neuroleptics. Psychopharmacologia 6:178-191

Mueser KT, Bellack AS, Brady EU (1990): Hallucinations in schizophrenia. Acta Psychiatr Scand 82:26-29

Muller P, Seeman P (1974): Neuroleptics: relation between cataleptic and anti-turning actions and role of the cholinergic system. J Pharm Pharmacol 26:981

Murzi E, Herberg LJ (1982): Anticholinergic treatment reverses haloperidol-induced blockade of self-stimulation of nucleus accumbens no less than of hypothalamus. Quart J Exp Psychol 34B:49-54

Nedergaard S, Bolam JP, Greenfield SA (1988): Facilitation of dendritic calcium conductance by 5-hydroxytryptamine in the substantia nigra. Nature 333:174-177

Parker GC, Rugg EL, Winn P (1991): Cholinergic stimulation of substantia nigra: abolition of carbachol-induced eating by unilateral 6-hydroxydopamine lesion of nigrostriatal dopamine neurons. Exp Brain Res 87:597-603

Peralta EG, Winslow JW, Peterson GL, Smith DH, Ashkenazi A, Ramachandran J, Schimerlick MI, Capon DJ (1987): Primary structure and biochemical properties of an M2 muscarinic receptor. Science 236:600-605

Pfeiffer CC, Jenney EH (1957): The inhibition of conditional response and counter action of schizophrenia by muscarinic stimulation of the brain. Ann NY Acad Sci 66: 753-764

Reavill C, Stolerman IP (1990): Locomotor activity in rats after administration of nicotinic agonists intracerebrally. Br J Pharmacol 99:273-278

Riemann D, Gann H, Fleckenstein P, Hohagen F, Olbrich R, Berger M (1991): Effects of RS 86 on REM latency in schizophrenia. Psychiatry Res 38:89-92

Rye DB, Saper CB, Lee HJ, Wainer BH (1987): Pedunculopontine nucleus of the rat: cytoarchitecture, cytochemistry, and some extrapyramidal connections of the mesopontine tegmentum. J Comp Neurol 259:483-528

Seeman P (1992): Dopamine receptor sequences. Therapeu- 
tic levels of neuroleptics occupy D2 receptors, clozapine occupies D4. Neuropsychopharm 7:261-284

Seeman P, Chau-Wong M, Tedesco J, Wong K (1975): Brain receptors for antipsychotic drugs and dopamine: Direct binding assays. Proc Natl Acad Sci USA 72:4376-4380

Semba K, Fibiger HC (1992): Afferent connections of the laterodorsal tegmental and the pedunculopontine tegmental nuclei in the rat: A retro- and antero-grade transport and immunohistochemical study. J Comp Neurol 323:387-410

Serafin M, Khateb A, Mülethaler M (1990): Opiates inhibit pedunculopontine neurones in guinea pig brainstem slices. Neurosci Lett 119:125-128

Setler P, Sarau H, McKenzie G (1976): Differential attenuation of some effects of haloperidol in rats given scopolamine. Eur J Pharmacol 39:117-126

Shannon HE, Peters SC (1990): A comparison of the effects of cholinergic and dopaminergic agents on scopolamineinduced hyperactivity in mice. J Pharm Exp Ther 255: 549-553

Shiromani PJ, Fishbein W (1986): Continuous pontine cholinergic microinfusion via mini-pump induces sustained alterations in rapid eye movement (REM) sleep. Pharmacol Biochem Behav 25:1253-1261

Shiromani PJ, Armstrong DM, Berkowitz A, Jeste DV, Gillin JC (1988): Distribution of choline acetyltransferase immunoreactive somata in the feline brainstem: Implications for REM sleep generation. Sleep 11:1-16

Singh MM, Kay SR (1975): Therapeutic reversal with benztropine in schizophrenics. J Nerv Mental Dis 169:258-266

Singh MM, Kay SR (1985): Pharmacology of central cholinergic mechanisms and schizophrenic disorders. In Singh MM, Warburton DM, Lal H (eds), Central Cholinergic Mechanisms and Adaptive Functions. New York, Plenum, pp 247-308

Singh MM, Kay SR, Opler LA (1987): Anticholinergicneuroleptic antagonism in terms of positive and negative symptoms of schizophrenia: Implications for psychobiological subtyping. Psychol Med 17:39-48

Singh MM, Smith JM (1973): Reversal of some therapeutic effects of an antipsychotic agent by an antiParkinsonism drug. J Nerv Ment Dis 157:50-58

Sitaram N, Moore AM, Gillin JC (1978): Induction and resetting of REM sleep rhythm in normal man by arecoline: Blockade by scopolamine. Sleep 1:83-90

Smith JM (1980): Abuse of the antiparkinson drugs: A review of the literature. J Clin Psychiatry 41:351-354

Snyder SH (1973): Amphetamine psychosis: A "model" schizophrenia mediated by catecholamines. Am J Psychiatry 130:61-67

Stephens DN, Herberg LJ (1979): Dopamine-acetylcholine "balance" in nucleus accumbens and corpus striatum and its effect on hypothalamic self-stimulation. Eur J Pharmacol 54:331-339

Steriade M, Datta S, Pare D, Oakson G, Curro Dossi R (1990): Neuronal activities in brain-stem cholinergic nuclei related to tonic activation processes in thalamocortical systems. J Neurosci 10:2541-2559

Sugimoto T, Hattori T (1984): Organization and efferent projections of nucleus tegmenti pedunculopontinus pars compacta with special reference to its cholinergic aspects. Neuroscience 11:931-946

Tandon R, Greden JF (1989): Cholinergic hyperactivity and negative schizophrenic symptoms: A model of cholinergic/dopaminergic interactions in schizophrenia. Arch Gen Psychiatry 46:745-753

Tandon R, Shipley JE, Greden JF, Mann MA, Eisner WH, Goodson J (1991): Muscarinic cholinergic hyperactivity in schizophrenia-relationship to positive and negative symptoms. Schiz Res 4:23-30

Tandon R, Shipley JE, Taylor S, Greden JF, Eiser A, DeQuardo J, Goodson J (1992): Electroencephalographic sleep abnormalities in schizophrenia: Relationship to positive/negative symptoms and prior neuroleptic treatment. Arch Gen Psychiatry 49:185-194

Taylor SF, Tandon R, Shipley JE, Eiser AS (1991): Effect of neuroleptic treatment on polysomnographic measures in schizophrenia. Biol Psychiatry 30:904-912

Tourlentes T, Axiotis A, Hunsiker A, Hurd D, Vassilon G, Abood LG (1960): Effects of new piperazinoglycolate on chronic schizophrenics. J Neuropsychiatr 2:49-53

Vilaro MT, Palacios JM, Mengod G (1990): Localization of m5 muscarinic receptor mRNA in rat brain examined by in situ hybridization histochemistry. Neurosci Lett 114: 154-159

Vilaro MT, Wiederhold K-H, Palacios JM, Mengod G (1991): Muscarinic cholinergic receptors in the rat caudateputamen and olfactory tubercle belong predominantly to the $\mathrm{m} 4$ class: In situ hybridization and receptor autoradiography evidence. Neuroscience 40:159-167

Vilaro MT, Wiederhold K-H, Palacios JM, Mengod G (1992): Muscarinic $m 2$ receptor $m R N A$ expression and receptor binding in cholinergic and non-cholinergic cells in the rat brain: A correlative study using in situ hybridization histochemistry and receptor autoradiography. Neuroscience 47:367-393

Vincent SR, Satoh K, Armstrong DA, Fibiger HC (1983): NADPH-diaphorase: A selective histochemical marker for the cholinergic neurons of the pontine reticular formation. Neurosci Lett 43:31-36

Wall SJ, Yasuda RP, Hory F, Flagg S, Martin BM, Ginns EI, Wolfe BB (1991a): Production of antisera selective for $m 1$ muscarinic receptors using fusion proteins: Distribution of $\mathrm{m} 1$ receptors in rat brain. Mol Pharmacol 39:643-649

Wall SJ, Yasuda RP, Li M, Wolfe BB (1991b): Development of an antiserum against $\mathrm{m} 3$ muscarinic receptors: Distribution of $\mathrm{m} 3$ receptors in rat tissues and clonal cell lines. Mol Pharmacol 40:783-789

Webster HH, Jones BE (1988): Neurotoxic lesions of the dorsolateral pontomesenephalic tegmentum-cholinergic cell area in the cat. II. Effects upon sleep-waking states. Brain Res 458:285-302

Weiner DM, Levey AI, Brann MR (1990): Expression of muscarinic acetylcholine and dopamine receptor mRNAs in rat basal ganglia. Proc Natl Acad Sci USA 87:7050-7054

Williams JA, Reiner PB (1992): Noradrenaline hyperpolarizes cholinergic neurons in rat laterodorsal tegmentum in vitro. Soc Neurosci Abstr 18:975

Wilson RE, Shagass C (1964): Comparison of two drugs with psychotomimetic effects (LSD and Ditran). J Nerv Ment Dis 138:277-286 
Winn P (1991): Cholinergic stimulation of substantia nigra: Effects on feeding, drinking, and sexual behaviour in the male rat. Psychopharmacology 104:208-214

Wise CD, Baden WM, Stein L (1974): Post-mortem measurement of enzymes in human brain: Evidence of a central noradrenergic deficit in schizophrenia. J Psychiatr Res 11:185-198

Woolf NJ (1991): Cholinergic systems in mammalian brain and spinal cord. Prog Neurobiol 37:475-524

Woolf NJ, Harrison JB, Buchwald JS (1990): Cholinergic neurons of the feline pontomesencephalon. II. Ascending anatomical projections. Brain Res 520:55-72

Yeomans JS (1992): Mesopontine cholinergic cells and mesolimbic dopamine functions, including schizophrenia. Soc Neurosci Abstr 18:911
Yeomans JS, Kofman O, McFarlane V (1985): Cholinergic involvement in lateral hypothalamic rewarding brain stimulation. Brain Res 329:19-26

Yeomans JS, Mathur A, Tampakeras M (1993): Rewarding brain stimulation: Role of tegmental cholinergic neurons that activate dopamine neurons. Behav Neurosci 107: 1077-1087

Yeomans JS, Mathur A, Shandarin A, Tampakeras (1994): Locomotion and stereotypy induced by cholinergic agents via tegmental receptors. Neuropsychopharm 10:151S

Ziskind A (1988): Transdermal scopolamine-induced psychosis. Postgraduate Medicine 84:73-76

Zweig RM, Whitehouse PJ, Casanova MF, Walker LC, Jankel WR, Price DL (1987): Loss of pedunculopontine neurons in progressive supernuclear palsy. Ann Neurol 22:18-25 